Brazilian Journal of Microbiology (2009) 40: 590-600

ISSN 1517-8382

\title{
MICROBIAL DIVERSITY IN A BAGASSE-BASED COMPOST PREPARED FOR THE PRODUCTION OF AGARICUS BRASILIENSIS
}

\section{Cristina Ferreira Silva; Raquel Santos Azevedo; Claudia Braga; Romildo da Silva; Eustáquio Souza Dias; Rosane Freitas Schwan*}

Departamento de Biologia, Universidade Federal de Lavras, Lavras, MG, Brasil

Submitted: September 03, 2008; Approved: May 03, 2009.

\begin{abstract}
Edible mushrooms are renowned for their nutritional and medicinal properties and are thus of considerable commercial importance. Mushroom production depends on the chemical composition of the basic substrates and additional supplements employed in the compost as well as on the method of composting. In order to minimise the cost of mushroom production, considerable interest has been shown in the use of agro-industrial residues in the preparation of alternative compost mixtures. However, the interaction of the natural microbiota present in agricultural residues during the composting process greatly influences the subsequent colonisation by the mushroom. The aim of the present study was to isolate and identify the microbiota present in a sugar cane bagasse and coast-cross straw compost prepared for the production of Agaricus brasilienses. Composting lasted for 14 days, during which time the substrates and additives were mixed every 2 days, and this was followed by a two-step steam pasteurisation $\left(55-65^{\circ} \mathrm{C} ; 15 \mathrm{~h}\right.$ each step). Bacteria, (mainly Bacillus and Paenibacillus spp. and members of the Enterobacteriaceae) were the predominant micro-organisms present throughout the composting process with an average population density of $3 \times 10^{8} \mathrm{CFU} / \mathrm{g}$. Actinomycetes, and especially members of the genus Streptomyces, were well represented with a population density of $2-3 \times 10^{8} \mathrm{CFU} / \mathrm{g}$. The filamentous fungi, however, exhibited much lower population densities and were less diverse than the other micro-organisms, although Aspergillus fumigatus was present during the whole composting process and after pasteurisation.
\end{abstract}

Key words: Agaricus brasiliensis, cane sugar bagasse; microbial diversity

\section{INTRODUCTION}

The mushroom species Agaricus brasiliensis (Cogumelo do sol), A. bisporus (Champignon), Pleurotus sajor-caju (Oyster mushroom) and Lentinula edodes (Shiitake) are of important economical value on account of their exquisite flavour and proven medicinal properties (27). Moreover, the organoleptic, nutritional and medicinal characteristics of $A$. brasiliensis (also known as $A$. blazei, but more correctly named $A$.

*Corresponding Author. Mailing address: Departamento de Biologia, Universidade Federal de Lavras, $37200-000$, Lavras, MG, Brazil.; Phone: +55 35

38291614 Fax: +55 353829 1341.; E-mail: rschwan@ufla.br 
subrufescens) have been recognised worldwide (2) and have assured a prime position for this species on the international market $(12,30,33)$.

In Brazil, the culture of $A$. brasiliensis is relatively recent, whilst productivity is variable and depends mainly on the type of substrate employed (12). The agronomic techniques involved in the culture of $A$. brasiliensis are similar to those used for A. bisporus except for some modifications in the preparation of the compost. While wheat straw, straw-bedded horse manure, chicken manure and gypsum (15) are typically employed as substrates in the commercial culture of mushrooms, there is considerable interest in finding cheaper and more readily available materials for compost production in which the $\mathrm{C}: \mathrm{N}$ ratio is between 25:1 and 50:1. In this context, the agricultural waste materials sugar-cane bagasse and coast-cross straw are considered to be potential substrates for the cultivation of $A$. brasiliensis in Brazil.

The composting process comprises two stages: in stage I the organic residues are wetted, distributed in layers and mixed periodically for up 2 weeks, while in the second stage the resulting compost is pasteurised and conditioned (4). Although, the final quality of the compost is determined by the overall composting process, success in mushroom production depends largely on stage II (27). During pasteurisation, microbial activity produces large quantities of heat that serve to eliminate many pests, pathogens and competing micro-organisms. In the conditioning stage, the thermophilic micro-organisms (especially the Actinomycetes) multiply and convert free ammonia into microbial protein. These micro-organisms perform a crucial role in the preparation of an appropriate mushroom compost since residual ammonia is highly toxic and hinders mycelia growth of Agaricus species, while the synthesised protein is important for the nutrition of the cultivated fungi $(4,8,31)$.
In view of the pivotal importance of the thermophilic micro-organisms that multiply and develop during stage I and act during stage II of composting, we undertook the task of evaluating the microbial diversity that occurs during the preparation of a compost based on sugar-cane bagasse and coast-cross straw.

\section{MATERIALS AND METHODS}

\section{Preparation of compost and sampling}

The raw materials present in the studied substrate mix were sugar cane (Saccharum officinarum L.) bagasse (45\%), coast-cross (Cynodon dactylon L. Pers.) straw (45\%) and wheat bran (10\%), supplemented with simple superphosphate $(1 \%), \mathrm{KCl}(1 \%)$, lime (2\%) and gypsum (2\%). The bagasse and coast-cross straw were thoroughly wetted and piled in uniform layers onto a wooden pallet. The pile was mixed every 2 days over a 2 week period, with a further addition of water in order to maintain the humidity at $65 \%$. During the second mixing, wheat bran and the inorganic supplements were added to the compost. Immediately before each mixing, the temperature was measured at a depth of $20 \mathrm{~cm}$ from the top of the pile and a substrate sample $(120 \mathrm{~g})$ was collected for microbiological analysis (counting and identification of the micro-organisms present). After each mixing, the humidity of the pile was determined and, if necessary, extra water was added to maintain humidity.

At the end of stage I (day 14), the compost was submitted to a two-step pasteurisation treatment in a chamber ( $2 \mathrm{~m}$ wide $\times 2 \mathrm{~m}$ high $\times 24 \mathrm{~m}$ deep) equipped with forced ventilation and steam injection systems. The time of pasteurisation $(15 \mathrm{~h})$ was measured from the moment the temperature in the chamber reached $60^{\circ} \mathrm{C}$, although temperatures of up to $65^{\circ} \mathrm{C}$ were recorded during the treatment. After the first pasteurisation step, the compost was removed from the chamber, mixed thoroughly and then 
submitted to a second pasteurisation step under identical conditions.

\section{Microbiological analysis}

A total of eight samples of substrate were obtained during stage I of composting before mixing the pile, on days $0,2,4,6,8,10,12$ and 14, and one sample was collected immediately after the pasteurisation procedure. Cell suspensions were prepared by mixing aliquots $(20 \mathrm{~g})$ of the samples in $180 \mathrm{~mL}$ of water containing $1 \%$ peptone and $5 \%$ $\mathrm{NaCl}$ and shaking the mixture thoroughly for $5 \mathrm{~min}$. Serial dilutions of each sample solution were prepared and inoculated onto Petri dishes containing the following selective media: (1) Martin's medium for the isolation of filamentous fungi $\left[\mathrm{KH}_{2} \mathrm{PO}_{4}(1.0 \mathrm{~g} / \mathrm{L}), \mathrm{MgSO}_{4} .7 \mathrm{H}_{2} \mathrm{O}(0.5\right.$ $\mathrm{g} / \mathrm{L})$, peptone $(5.0 \mathrm{~g} / \mathrm{L})$, dextrose $(10.0 \mathrm{~g} / \mathrm{L})$, Rose Bengal dye (0.038 g/L), agar (20 g/L), bacitracin (20 mg/L)], (2) YEPG medium for yeast isolation [yeast extract $(5.0 \mathrm{~g} / \mathrm{L})$, peptone $(10 \mathrm{~g} / \mathrm{L})$, glucose $(20 \mathrm{~g} / \mathrm{L})$, agar $(20 \mathrm{~g} / \mathrm{L})$; adjusted to $\mathrm{pH} 4.5]$, (3) Aaronson's medium for the isolation of Actinomycetes $\left[\mathrm{KNO}_{3}(2.0 \mathrm{~g} / \mathrm{L})\right.$, casein $(0.8 \mathrm{~g} / \mathrm{L}), \mathrm{NaCl}(2.0 \mathrm{~g} / \mathrm{L}), \mathrm{K}_{2} \mathrm{HPO}_{4}$ $(2.0 \mathrm{~g} / \mathrm{L})$, agar $(20.0 \mathrm{~g} / \mathrm{L}), \mathrm{MgSO}_{4} \cdot \mathrm{H}_{2} \mathrm{O}(50 \mathrm{mg} / \mathrm{L}), \mathrm{CaCO}_{3}$ $\left.(20.0 \mathrm{~g} / \mathrm{L}), \mathrm{FeSO}_{4} .7 \mathrm{H}_{2} \mathrm{O}(40.0 \mathrm{~g} / \mathrm{L})\right]$, and (4) nutrient agar for the isolation of bacteria [meat extract $(3.0 \mathrm{~g} / \mathrm{L})$, peptone 5.0 $\mathrm{g} / \mathrm{L}$, agar $(20.0 \mathrm{~g} / \mathrm{L})]$. Plates were incubated at $40^{\circ} \mathrm{C}$ for $48 \mathrm{~h}$, after which the number of colony forming units (CFU) were counted and the microbial content of each substrate sample expressed in terms of CFU/g. From each type of medium on which isolated colonies were detected, a number equal to the square root of the total colonies were taken at random (16), and purified and stored in $20 \%$ glycerol at $-80^{\circ} \mathrm{C}$ for subsequent identification.

\section{Identification of bacteria}

The size, shape, colour, height and edge characteristics of each purified colony were noted, and the colonies were submitted to Gram-staining and assayed for motility and the presence of catalase before being replicated onto plate count agar (PCA) slants and stored in $20 \%$ glycerol at $-80^{\circ} \mathrm{C}$. Gramnegative bacteria were identified with the aid of Difco BacTray Kits I, II and III used according to the manufacturer's instructions. Gram-positive bacteria were subdivided into sporulating and non-sporulating species by inducing spore release at $80^{\circ} \mathrm{C}$ for $10 \mathrm{~min}$, and subsequently identified from the results of biochemical and motility assays $(14,16)$. Identities were confirmed using API galleries (BioMerieux, Marcy-l'Etoile, France).

\section{Identification of Actinomycetes}

The genera of isolates were identified according to standard morphological methods $(16,28)$. Isolates were examined for their abilities to utilise a range of substrates (i.e. sucrose, lactose, D-fructose, galactose, d-mannose, Dmaltose, xylose, L-arabinose, cellobiose, rhamnose, sodium acetate and m-inositol) as sole carbon source. Each filtered and sterilised carbon source was added to carbon utilisation agar (ISP medium 9) $(28,37)$ at a concentration of $1.0 \%$ $(w / v)$, with the exception of sodium acetate which was employed at $0.1 \%(\mathrm{w} / \mathrm{v})$. Positive (glucose at $1.0 \% \mathrm{w} / \mathrm{v})$ and negative (unsupplemented ISP 9) controls were included, and growth was evaluated after 7,14 and 21 days.

The formation of acids by Actinomycetes in the presence a carbon source was determined by inoculating a double washed (sterile distilled water) spore suspension of an isolate onto a plate containing a basal medium $\left[\left(\mathrm{NH}_{4}\right)_{2} \mathrm{HPO}_{4}(1.0\right.$ $\mathrm{g} / \mathrm{L}), \mathrm{KCl}(0.2 \mathrm{~g} / \mathrm{L}), \mathrm{MgSO}_{4} \cdot 7 \mathrm{H}_{2} \mathrm{O}(0.5 \mathrm{~g} / \mathrm{L})$, bromocresol purple $(0.07 \mathrm{~g} / \mathrm{L})$, agar $(15 \mathrm{~g} / \mathrm{L})]$ supplemented with the substrate. The results were considered to be positive when the colour of the medium changed from blue to yellow. Pigment formation was determined on glycerol/asparagine agar (ISP medium 5) after 14 days of incubation, and diffusible pigments were classified as brown, yellow, green or orange. 
Melanin production was detected on tyrosine agar (ISP medium 7), and the formation of the dark brown to black soluble melanin pigment was recorded after 4 days of incubation (28).

\section{Identification of filamentous fungi}

The initial identification of the genera of fungal cultures grown on potato dextrose agar medium (Merck) was performed by morphotype analysis (particularly colour and appearance) under the optical microscope (21). Members of the genus Aspergillus were identified by microscopic examination of spores and mycelia, and subsequently classified further into the sections Circumdati (6), Flavi (7), Nigri and Aspergillus (17). Fungal identities were verified on the basis of literature data $(21,22,26)$.

\section{RESULTS AND DISCUSSION}

A total of 570 microbial colonies were isolated from the experimental samples and analysed. A wide diversity in the number of individuals and species of bacteria, Actinomycetes and filamentous fungi present in the substrate was observed during the composting process. The levels of relative humidity during composting ranged from 68.5 to $74 \%$, but this factor apparently had little effect on the growth and development of the micro-organisms. The highest temperatures (up to $62.6^{\circ} \mathrm{C}$ ) were observed during the first 8 days of composting, and these probably resulted from the presence of the nutritional supplements that were added at the beginning of the process. According to Colak (8), the ideal composting temperature varies between 35 and $55^{\circ} \mathrm{C}$, since under such conditions any ammonia produced is quickly removed and the substrate undergoes physical and chemical modifications conferring characteristics to the final compost that are most suitable for the growth of Agaricus bisporus.
The composting process is initiated by mesophilic microorganisms that utilise simple carbohydrates and soluble nitrogen compounds (29). The rise in the internal temperature of the pile produced by the exothermic reactions of the microbiota establishes suitable conditions for the development of thermotolerant and thermophilic populations (Gram-positive bacteria and Actinomycetes), which also predominate after the thermophilic phase (3). These microorganisms are essential for the selective properties of the compost that favour the growth of the mycelia of Agaricus species but are less suitable for competing organisms (13).

The initial population of micro-organisms in the bagasse and coast-cross straw mix was $3.2 \times 10^{8} \mathrm{CFU} / \mathrm{g}$, of which $94 \%$ were bacterial species. The population density increased to an average of $7.1 \times 10^{8} \mathrm{CFU} / \mathrm{g}$ between the $2^{\text {nd }}$ and $10^{\text {th }}$ days of composting, after which it fell back to $5.7 \times 10^{8}$ $\mathrm{CFU} / \mathrm{g}$ by the $14^{\text {th }}$ day. Pasteurisation reduced the total microbial population even further by virtue of the high temperatures $\left(>60^{\circ} \mathrm{C}\right)$ applied.

The occurrence of bacteria, and especially of species of Bacillus, was observed in the bagasse and coast-cross straw mix during all of the composting stage, with an average population density of $3 \times 10^{8} \mathrm{CFU} / \mathrm{g}$. Indeed, throughout composting, the bacteria formed the most predominant and numerous group of micro-organisms present, followed by the Actinomycetes and then the filamentous fungi (Fig.1). Similar results have been reported in the composting of wheat (1) and rice straw (3) in which prokaryotes together with a few fungi predominated during the earliest days of composting, whilst the Actinomycetes prevailed during the final period.

In the present study, 13 Gram-negative and 20 Grampositive bacteria were identified in the substrate during composting and after pasteurisation (Table 1). All of the bacteria isolated are very common in soils and are natural 
contaminants of agricultural residues, appearing mainly after harvesting and processing. Eighteen of the Gram-negative species belonged to the family Enterobacteriaceae while a further 6 were Pseudomonas species. With respect to the Gram-positive species, 8 were members of the genus Bacillus (Table 1). Species of Bacillus and Pseudomonas, as well as members of the Actinomycetes, are believed to play important roles in the assimilation and transformation of ammonia (25), whilst Pseudomonas putida is reported to exert a positive effect on the fructification of $A$. bisporus (10).

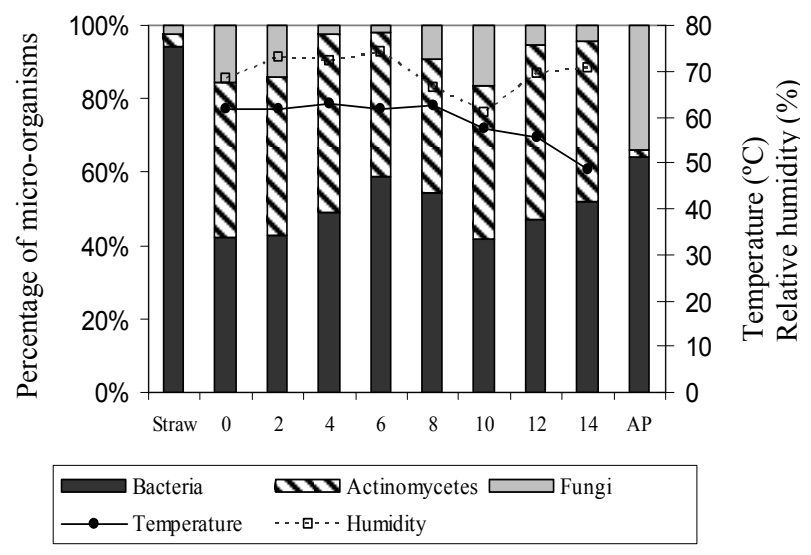

Figure 1. Percentage of micro-organisms present in the original compost materials (Straw), and in the substrate during composting and after pasteurisation (AP). The lines represent the dynamics of temperature $\left({ }^{\circ} \mathrm{C}\right)$ and humidity $(\%)$ during the 14 days of composting of a substrate based on sugar cane bagasse and coast-cross grass

A number of pathogenic species, including Enterobacter agglomerans, Escherichia coli and Klebsiella pneumoniae, were also isolated from bagasse and coast-cross straw during stage I composting. E. coli was still detectable after pasteurisation for $30 \mathrm{~h}$, demonstrating that steam pasteurisation is not sufficient to eliminate this contaminant. It has been reported that temperatures of between $54-70^{\circ} \mathrm{C}$ greatly influence the activity and diversity of microorganisms in edible mushroom compost (20). Moreover, $E$. coli, Salmonella and other pathogenic species, including $B$. subtilis and B. pumilus, have been isolated from both stage I and II composts, and it is believed that such mesophilic bacteria are able to survive temperatures $>55^{\circ} \mathrm{C}$ through mechanisms of thermoresistance acquired by genetic mutation (9).

The microbiota present in bagasse and coast-cross straw prior to composting was very similar to those found on day 0 and day 2 of composting, and consisted mainly of $B$. circulans and B. licheniformis. The bacterial population altered notably during composting since, from the first day of mixing and onwards, other species of Bacillus were detected including B. subtilis, B. pumilus, B. sphaericus, $B$. amyloliquefaciens and B. anthracis. Gbolagade (13) also identified various species of Bacillus in compost prepared for the culture of Pleurotus tuber-regium and Lentinus squarrosulus. This author has suggested that Bacillus bacteria may stimulate the growth of cellulolytic thermophilic Actinomycetes, since the latter appeared in the substrate after the $2^{\text {nd }}$ day of composting when the diversity of Bacillus was greatest. Species of Paenibacillus and Bacillus were also reported to be the most predominant Gram-positive bacteria in wheat straw-based compost employed in the culture of Pleurotus ostreatus (35). Apparently, these bacterial species promote the growth of the mushroom by secreting laccases and inhibiting the growth of Trichoderma harzianum. Additionally, species of Bacillus and Paenibacillus synthesise and excrete toxic peptides, the bacteriocins, which are capable of inhibiting the growth of yeast as well as 
Table 1. Diversity of micro-organisms present in sugar cane bagasse and coast-cross straw before and during the composting process and after pasteurisation

\begin{tabular}{|c|c|c|c|}
\hline Sample (CFU/g) & Bacteria $^{a}$ & Actinomycetes $^{\mathrm{a}}$ & Filamentous fungi $^{\mathrm{a}}$ \\
\hline $\begin{array}{l}\text { Bagasse and coast-cross straw } \\
\text { Total population } \\
3.2 \times 10^{8}\end{array}$ & $\begin{array}{l}\text { Acinetobacter sp } \\
\text { Bacillus circulans (4) } \\
\text { Bacillus licheniformis } \\
\text { Enterobacter agglomerans } \\
\text { Klebsiella oxytora } \\
\text { Paenibacillus polymyxa (3) } \\
\text { Pseudomonas putida } \\
\text { Tatumella ptyseos }\end{array}$ & Streptomyces & Aspergillus fumigatus (5) \\
\hline $\begin{array}{l}\text { Day } 0 \text { of composting } \\
\text { Total population } \\
7.1 \times 10^{8}\end{array}$ & $\begin{array}{l}\text { Paenibacillus polymyxa } \\
\text { Bacillus coagulans } \\
\text { Bacillus licheniformis } \\
\text { Bacillus megaterium } \\
\text { Brevibacillus brevis } \\
\text { Enterobacter agglomerans (3) } \\
\text { Enterobacter gergoviae } \\
\text { Pseudomonas paucimobilis } \\
\text { Serratia marcescens } \\
\text { Serratia plymutica } \\
\text { Serratia odorifera }\end{array}$ & Streptomyces & $\begin{array}{l}\text { Aspergillus fumigatus (11) } \\
\text { Aspergillus niger (3) }\end{array}$ \\
\hline $\begin{array}{l}\text { Day } 2 \text { of composting } \\
\text { Total population } \\
7.0 \times 10^{8}\end{array}$ & $\begin{array}{l}\text { Bacillus circulans (2) } \\
\text { Bacillus subtilis } \\
\text { Bacillus pumilus } \\
\text { Paenibacillus polymyxa } \\
\text { Enterobacter agglomerans (2) } \\
\text { Pseudomonas aeruginosa } \\
\text { Klebsiella rhinoscleromatis } \\
\end{array}$ & Streptomyces & $\begin{array}{l}\text { Aspergillus fumigatus (16) } \\
\text { Aspergillus niger (4) }\end{array}$ \\
\hline $\begin{array}{l}\text { Day } 4 \text { of composting } \\
\text { Total population } \\
6.1 \times 10^{8}\end{array}$ & $\begin{array}{l}\text { Bacillus megaterium (2) } \\
\text { Paenibacillus polymyxa } \\
\text { Paenibacillus macerans } \\
\text { Klebsiella pneumoniae (2) } \\
\text { Serratia odorifera }\end{array}$ & Streptomyces & $\begin{array}{l}\text { Aspergillus fumigatus (22) } \\
\text { Aspergillus niger (2) }\end{array}$ \\
\hline $\begin{array}{l}\text { Day } 6 \text { of composting } \\
\text { Total population } \\
5.1 \times 10^{8}\end{array}$ & $\begin{array}{l}\text { Bacillus circulans (2) } \\
\text { Bacillus sphaericus (3) } \\
\text { Bacillus pumilus } \\
\text { Bacillus licheniformis } \\
\text { Bacillus megaterium } \\
\text { Paenibacillus macerans } \\
\text { Acinetobacter sp } \\
\text { Pseudomonas vesiculares } \\
\text { Tatumella ptyseos } \\
\text { Flavobacterium odoratum }\end{array}$ & $\begin{array}{l}\text { Micronaspora }(2) \\
\text { Streptomyces }\end{array}$ & Aspergillus fumigatus (20) \\
\hline $\begin{array}{l}\text { Day } 8 \text { of composting } \\
\text { Total population } \\
5.5 \times 10^{8}\end{array}$ & $\begin{array}{l}\text { Bacillus amyloliquefaciens } \\
\text { Bacillus licheniformis } \\
\text { Bacillus pumilus } \\
\text { Paenibacillus polymyxa (3) } \\
\text { Enterobacter agglomerans } \\
\text { Enterobacter aerogenes } \\
\text { Enterobacter cloacae } \\
\text { Pseudomonas fluorecens } \\
\text { Klebsiella rhinoscleromatis } \\
\text { Serratia odorifera (2) }\end{array}$ & Streptomyces & Aspergillus fumigatus (13) \\
\hline
\end{tabular}


Azevedo, R.S. et al.

\begin{tabular}{|c|c|c|c|}
\hline $\begin{array}{l}\text { Day } 10 \text { of composting } \\
\text { Total population } \\
6.2 \times 10^{8}\end{array}$ & $\begin{array}{l}\text { Bacillus macerans } \\
\text { Bacillus circulans (2) } \\
\text { Corynebacterium sp } \\
\text { Klebsiella pneumoniae }\end{array}$ & Streptomyces (2) & A. fumigatus (22) \\
\hline $\begin{array}{l}\text { Day } 12 \text { of composting } \\
\text { Total population } \\
6.4 \times 10^{8}\end{array}$ & $\begin{array}{l}\text { Bacillus cereus } \\
\text { Bacillus circulans (2) } \\
\text { Acinetobacter } \mathrm{sp} \\
\text { Escherichia coli } \\
\text { Enterobacter agglomerans } \\
\text { Pseudomonas putida } \\
\end{array}$ & $\begin{array}{l}\text { Micronospora }(5) \\
\text { Nocardia }(2) \\
\text { Streptomyces } \\
\text { Thermonospora }(2)\end{array}$ & A. fumigatus (21) \\
\hline $\begin{array}{l}\text { Day } 14 \text { of composting } \\
\text { Total population } \\
5.8 \times 10^{8}\end{array}$ & $\begin{array}{l}\text { Bacillus anthracis } \\
\text { Bacillus licheniformis (2) } \\
\text { Bacillus megaterium } \\
\text { Enterobacter agglomerans } \\
\text { Pseudomonas stutzeri }\end{array}$ & $\begin{array}{l}\text { Dactylosporangium (3) } \\
\text { Kibdelosporangium } \\
\text { Nocardia } \\
\text { Streptomyces (5) } \\
\text { Thermonospora (3) }\end{array}$ & A. fumigatus (8) \\
\hline $\begin{array}{l}\text { After pasteurisation } \\
\text { Total population } \\
4.7 \times 10^{8}\end{array}$ & $\begin{array}{l}\text { Bacillus circulans (2) } \\
\text { Paenibacillus alvei } \\
\text { Paenibacillus polymyxa (3) } \\
\text { Escherichia coli }\end{array}$ & $\begin{array}{l}\text { Streptomyces (9) } \\
\text { Nocardia }\end{array}$ & A. fumigatus (7) \\
\hline
\end{tabular}

Gram-positive and Gram-negative bacteria (39).

In the present study, the incidence of Gram-negative bacteria was found to be greater on days 0 and 8 of composting in comparison with the other days, and the species identified were similar to those isolated from other types of compost (32). Various genera of Gram-negative bacteria, especially Pseudomonas and Acinetobacter, possess strong oxidative properties and are able to stimulate mycelia growth and the formation of fructification bodies in Pleurotus ostreatus (5). Additionally, species of Enterobacter, Klebsiella and Escherichia, together with Bacillus, are important for nitrogen fixation and in the solubilisation and release of phosphorus in the compost (32). Pasteurisation does not diminish the viability of these micro-organisms since the bacterial population was larger following this procedure than at any other point during the composting, and this is important for the maintenance of the natural microbiota of the compost.

The second largest population of micro-organisms in natural bagasse and coast-cross straw were the Actinomycetes with ca. $1 \times 10^{7} \mathrm{CFU} / \mathrm{g}(3.8 \%$ of the total population, Fig.1). During composting the population of Actinomycetes increased remarkably (up to $2.0-3.0 \times 10^{8}$ $\mathrm{CFU} / \mathrm{g}$ ) especially between days 2 and 4, and between days 10 and 12. Streptomyces spp. were the only Actinomycetes that could be isolated during all steps of the composting process, whilst members of the genera Nocardia, Micromonospora, Thermomonospora Dactylosporangium and Kibdelosporangium were variously detected on days 6, 12 and 14 of composting. Streptomyces and Nocardia were, however, the only Actinomycetes found after pasteurisation.

Actinomycetes are important for the preparation of compost suitable for colonisation by Agaricus since they degrade cellulose, thus diminishing the fibre content, and secrete biotin, thiamine and vitamin A. Moreover, Actinomycetes and some thermophilic fungi predominate at the end of stage II of composting (23), resulting in a reduction in the concentration, or the complete disappearance, of ammonia that is toxic for the Agaricus mushroom (36). When the compost cools down (to around $25^{\circ} \mathrm{C}$ ) the thermophilic organisms become dormant and the biomass is subsequently digested by the Agaricus. A 
significant reduction in Actinomycetes during steam pasteurisation is thus unfavourable to the production of high quality compost, even though such a strategy is employed by many small farmers who do not have access to the appropriate infrastructure by which to fully implement stage II composting.

The population of filamentous fungi was low during stage I of composting with a maximum size $\left(1.2 \times 10^{8}\right.$ $\mathrm{CFU} / \mathrm{g} ; 16.7 \%$ of the total population) being attained on day 10 (Fig.1). However, the density of these organisms increased to $1.6 \times 10^{8} \mathrm{CFU} / \mathrm{g}$ ( $34 \%$ of the total population) after pasteurisation, demonstrating that the thermoresistance of these organisms was second only to that of bacteria (population $3.0 \times 10^{8} \mathrm{CFU} / \mathrm{g}$ ). The main role of the thermoresistant filamentous fungi that colonise compost material is to degrade lignocelluloses (34), thus diminishing the amount of fibre and increasing the availability of substrate for Agaricus. Although filamentous fungi are essential for the transformation of the natural plant substrate into compost $(24,36)$, this group was the least diversified with only two species (Aspergillus fumigatus and A. niger) being identified during the composting process. It is possible that other species were present in the compost, including those that do not produce asexual spores, but for their isolation it would be necessary to use techniques other than those used in the present study. A. fumigatus was detected throughout stages I and II of composting, and its presence has also been reported in wheat straw-based compost as well (11). Although A. fumigatus is an opportunist pathogen that can produce allergic reactions in individuals that are exposed to the spores or are immunosuppressed $(18,19)$, this fungus excretes thermostable cellulases $(38,40)$ that permit the release of soluble sugars and favour microbial succession during composting (4).
Following pasteurisation, the compost biomass contains high concentrations of organic and inorganic nutrients that favour the colonisation of edible mushrooms. In the present study, the species identified after pasteurisation of compost were B. circulans, Paenibacillus alvei, P. polymyxa and E. coli. The occurrence of $B$. circulans (a sporulating bacterium) at this stage can be explained by its strong thermoresistance, whilst the occurrence of Paenibacillus spp. and E. coli (nonsporulating bacteria) may be explained by the protective effect of the organic material present in the compost. No Gram-negative bacteria were isolated from the compost after pasteurisation. Although the population of Actinomycetes decreased remarkably as a result of pasteurisation, some Streptomyces persisted, thus demonstrating their resistance to temperatures of up $65^{\circ} \mathrm{C}$.

In conclusion, compost based on sugar cane bagasse and coast-cross straw supported a diverse microbial population, consisting mainly of Bacillus spp, Streptomyces and Aspergillus fumigatus, which are responsible for the degradation of fibres and for the physical and chemical characteristics of the final compost. These species were the most persistent micro-organisms during stage $I$ of composting and the most thermostable during pasteurisation. Low cost substrates, such as solid agro- industrial residues, are an economical alternative mainly because they are constantly available irrespective of the season, and are readily converted into an adequate mushroom substrate without requiring refined technology.

\section{ACKNOWLEDGEMENTS}

The authors wish to thank Fundação de Amparo à Pesquisa de Minas Gerais (FAPEMIG), Conselho Nacional de Desenvolvimento Científico e Tecnológico (CNPq) and 
Azevedo, R.S. et al.

Coordenação de Aperfeiçoamento de Pessoal de Nível Superior (CAPES) for financial support.

\section{RESUMO}

\section{Diversidade microbiana em composto a base de bagaço de cana preparado para produção de Agaricus brasiliensis.}

Os cogumelos comestíveis são apreciados pelas suas propriedades nutricionais e medicinais e, por essa razão, possuem alto valor econômico. A produção de cogumelos depende da composição química dos substratos básicos, dos suplementos utilizados e da preparação do composto no qual o fungo será cultivado. Considerando-se que os custos de produção precisam ser minimizados, os resíduos agroindustriais representam uma fonte alternativa e econômica para a preparação do composto. A interação da microbiota natural dos resíduos agrícolas durante o processo de compostagem influencia a subseqüente colonização do cogumelo. Visando-se a produção de A. brasiliensis, o presente trabalho objetivou isolar e identificar a microbiota presente no composto preparado a partir de bagaço de cana e capim coast-cross. O processo de compostagem durou 14 dias com reviragens da pilha a cada dois dias, o qual foi seguido de pasteurização $\left(55-65^{\circ} \mathrm{C}\right)$ em duas fases por $15 \mathrm{~h}$ cada. As bactérias (principalmente Bacillus, Paenibacillus e espécies da família Enterobacteriaceae) foram os microrganismos predominantes durante todo o processo com uma densidade populacional média de $3.0 \times 10^{8} \mathrm{UFC} / \mathrm{g}$. Os actinomicetos, principalmente os do gênero Streptomyces, estiveram bem representados, com uma densidade populacional de 2.0 a 3.0 x $10^{8} \mathrm{UFC} / \mathrm{g}$. Os fungos filamentosos foi a classe de microrganismos com menor densidade populacional e menor diversidade, embora a espécie Aspergillus fumigatus esteve presente durante todo o processo de compostagem e também após a pasteurização do composto.

Palavras-chaves: Agaricus brasiliensis, bagaço de cana, diversidade microbiana.

\section{REFERENCES}

1. Atkey, P.T.; Wood, D.A. (1983). An electron microscope study of wheat straw composted as a substrate for the cultivation of the edible mushroom (Agaricus bisporus). J. Appl. Microbiol., 55, 293-304.

2. Bellini, M.F.; Cabrioti, L.N.; Terezan, A.P.; Jordão, B.Q.; Ribeiro, L.R.; Mantovani, M.S. (2008). Cytotoxicity and genotoxicity of Agaricus blazei methanolic extract fractions assessed using gene and chromosomal mutation assays. Genet. Mol. Biol., 31, 122-127.

3. Cahyani, V.R.; Matsuya, K.; Asakawa, S.; Kimura, M. (2004). Succession and phylogenetic profile of eukaryotic communities in the composting process of rice straw estimated by PCR-DGGE analysis Biol. Fertil. Soils, 40, 334-344.

4. Chang, S.T., Miles, P.G. (2004). Mushrooms: Cultivation, Nutritional Value, Medicinal Effect, and Environmental Impact. CRC Press, Boca Raton, FL.

5. Cho, Y.S.; Kim, J.S.; Crowley, D.E.; Cho, B.G. (2003). Growth promotion of the edible fungus Pleurotus ostreatus by fluorescent pseudomonads. FEMS Microbiol. Lett., 218, 271-276.

6. Christensen, M. (1981). A synoptic key and evaluation of species in the Aspergillus flavus group. Mycologia, 73, 1056-1084.

7. Christensen, M. (1982). The Aspergillus ochraceus group: Two new species from western soils and a synoptic key. Mycologia, 74, 210-225.

8. Colak, M. (2004). Temperature profiles of Agaricus bisporus in composting stages and effects of different composts formulas and casing materials on yield. African J. Biotechnol., 3, 456-462.

9. Droffner, M.L.; Brinton Jr., W.F.; Evans, E. (1995). Evidence for the prominence of well characterized mesophilic bacteria in thermophilic (50-70 $\left.{ }^{\circ} \mathrm{C}\right)$ composting environments. Biomass Bioenergy, 8, 191-195.

10. Eger, G. (1972). Experiments and comments on the action of bacteria on sporophore initiation in Agaricus bisporus. Mushroom Sci., 8, 719725.

11. Fermor, T.R.; Randle, P.E.; Smith, J.F. (1985). Compost as substrate and its preparation. In: Flegg, P.B.; Spencer, D.M; Wood, D.A. (eds). 
The Biology and Technology of the Cultivated Mushroom. John Wiley, Chichester, UK. p.81-109.

12. Firenzuoli, F.; Gori, L.; Lombardo, G. (2007). The medical mushroom Agaricus blazei Murril. Literature and pharmaco-toxicological problems. e-CAM, 5, 3-15.

13. Gbolagade, J.S. (2006). Bacteria associated with compost used for the cultivation of Nigerian edible mushroom Pleurotus tuber-regium (Fr.) Singer and Lentinus squarrosulus (Berk.). African J. Biotechnol., 5, 338-342.

14. Hammes, W.P.; Hertel, C. (2003). The genera Lactobacillus and Carnobacterium. In: Dworkin, M. (ed.). The Prokaryotes: An Evolving Electronic Resource for the Microbiological Community, $3^{\text {rd }}$ Edn. Springer Verlag, New York, NY. p. 320-403.

15. Have, R.T.; Wijngaard, H.; Aries-Kronenburg, N.A.E.; Straatsma, G.; Schaap, P.J. (2003). Lignin degradation by Agaricus bisporus accounts for a $30 \%$ increase in bioavailable holocellulose during cultivation on compost. J. Agric. Food Chem., 51, 2242-2245.

16. Holt, J.G.; Krieg, N.R.; Sneath, P.H.A.; Staley, J.T.; Williams, S.T. (1994). Bergey's Manual of Determinative Bacteriology, $9^{\text {th }}$ Edn. Williams and Wilkins, Baltimore, MD.

17. Klich, M.A.; Pitt, J.I. (1988). A Laboratory Guide to Common Aspergillus Species and their Teleomorphs. CSIRO Division of Food Processing, North Ryde, Australia.

18. Latgé, J.P. (1999). Aspergillus fumigatus and aspergillosis. Clin. Microbiol. Rev., 12, 310-350.

19. Latgé, J.P. (2001). The pathobiology of Aspergillus fumigatus. Trends Microbiol., 9, 382-389.

20. Miyatake, F.; Iwabuchi, K. (2005). Effect of high compost temperature on enzymatic activity and species diversity of culturable bacteria in cattle manure compost. Biores. Technol., 96, 1821-1825.

21. Pitt, J.I.; Hocking, A.D. (1997). Fungi and Food Spoilage, $2^{\text {nd }}$ Edn. Chapman and Hall, Cambridge, UK.

22. Raper, K.B.; Fennell, D.I. (1965). The Genus Aspergillus. Williams and Wilkins, Baltimore, MD.

23. Ross, R.C.; Harris, P.J. (1983). The significance of thermophilic fungi in mushroom compost. Sci. Hort., 20, 61-70.

24. Ryckeboer, J.; Mergaert, J.; Coosemans, J.; Deprins, K.; Swings, J. (2003). Microbiological aspects of biowaste during composting in a monitored compost bin. J. Appl. Microbiol., 94, 127-137.

25. Ryckeboer, J.; Mergaert, J.; Vaes, K.; Klammer, S.; De Clerco, D.; Coosemans, J.; Insam, H.; Swings, J. (2003) A survey of bacteria and fungi occurring during composting and self-heating process. Ann. Microbiol., 53, 349-410.
26. Samson, R.A.; Hoekstra, E.S.; Frisvad, J.C.; Filtenborg, O. (1995). Introduction to Food-Borne Fungi, $4^{\text {th }}$ Edn. Centraalbureau Voor Schimmelcultures, Baarn, The Netherlands.

27. Sánchez, C. (2004). Modern aspects of mushroom culture technology. Appl. Microbiol. Biotechnol., 64, 756-762.

28. Shirling, E.B.; Gottlieb, D. (1966). Methods for the characterization of Streptomyces species. Int. J. Syst. Bacteriol., 16, 313-340.

29. Smith, J.F.; Wood, D.A.; Thurston, C.F. (1995). Growth measurement of Agaricus mycelium in composed substrates as an indicator of compost selectivity and mushroom productivity. In: Elliot, T.J. (Ed). Science and Cultivation of Edible Fungi. Balkema, Rotterdam.

30. Stijve, T.; Amazonas, M.A.L.A.; Giller, V. (2002). Flavor and Taste Components of Agaricus brasiliensis ssp. Heinenm: a New Gourmet and Medical Mushroom. Deutsche Lebensmitel-Rundschau, Stuttgart, Germany.

31. Straatsma, G.; Banson, R.A.; Olijnsma, T.W. (1994). Ecology of thermophilic fungi in mushroom compost, with emphasis on Scytalidium thermophilum and growth stimulation of Agaricus bisporus mycelium. Appl. Environ. Microbiol., 60, 454-458.

32. Subbarao, N.S. (1992). Biofertilizers in Agriculture, $2^{\text {nd }}$ Edn. Oxford and IBH Publishing, New Delhi, India.

33. Takaku, T.; Kimura, Y.; Okuda, H. (2001). Isolation of an antitumor compound from Agaricus brasiliensis Murril. and its mechanism of action. J. Nutr. 131, 1409-1413.

34. Tuomela, M.; Vikman, M.; Ataca, A.; Itävaara M. (2000). Biodegradation of lignin in a compost environment: a review. Biores. Technol., 72, 169-183.

35. Velázquez-Cedeño, M.; Farnet, A.M.; Mata, G.; Savoie, J.M. (2008). Role of Bacillus spp. in antagonism between Pleurotus ostreatus and Trichoderma harzianum in heat-treated wheat-straw substrates. Biores. Technol. [doi 10.1016/j.biortech.2008.01.022]

36. Vijay, B.; Gupta, Y. (1994). Microflora of Agaricus bisporus compost. In: Nair, M.C. (ed). Advances in Mushroom Biotechnology. Scientific Publishers, Jodhpur, India.

37. Vijayalakshmi, K.; Vijayalakshmi, M. (2007). Studies on cultural, physiological and antimicrobial activities of Streptomyces rochei. $J$. Appl. Sci. Res., 3, 2026-2029.

38. Vries, R.P.; Visser, J. (2001). Aspergillus enzymes involved in the degradation of plant cell wall polysaccharides. Microbiol. Mol. Biol. Rev., 65, 497-522.

39. Watabe, M.; Rao, J.R.; Murphy, A.R.; Moore, J.E. (2003). Inhibition of Listeria ivanovii by Paenibacillus lentimorbus isolated from phase II mushroom compost. World J. Microbiol. Biotechnol., 19, 875-877. 
Azevedo, R.S. et al.

40. Ximenes, E.A.; Felix, C.R.; Ulhoa, C.J. (1996). Production of cellulases by Aspergillus fumigatus and characterization of one $\beta$ glucosidase. Curr. Microbiol., 32, 119-123. 